\title{
Fiscal Transparency and Economic Outcomes
}

\author{
Farhan Hameed
}





\title{
IMF Working Paper
}

Fiscal Affairs Department

\section{Fiscal Transparency and Economic Outcomes}

\author{
Prepared by Farhan Hameed ${ }^{1}$ \\ Authorized for distribution by Teresa Ter-Minassian
}

December 2005

\begin{abstract}

\section{This Working Paper should not be reported as representing the views of the IMF.} The views expressed in this Working Paper are those of the author(s) and do not necessarily represent those of the IMF or IMF policy. Working Papers describe research in progress by the author(s) and are published to elicit comments and to further debate.
\end{abstract}

This paper develops indices of fiscal transparency for a broad range of countries based on the IMF's Code of Good Practices on Fiscal Transparency, using data derived from published fiscal transparency modules of the Reports on the Observance of Standards and Codes (ROSCs). The indices covers four clusters of fiscal transparency practices: data assurances, medium-term budgeting, budget execution reporting, and fiscal risk disclosures. More transparent countries are shown to have better credit ratings, better fiscal discipline, and less corruption, after controlling for other socioeconomic variables.

JEL Classification Numbers: E62, E44, P0

Keywords: Fiscal Transparency, Credit Ratings, Fiscal Discipline, Corruption, Institutions Author(s) E-Mail Address: fhameed@imf.org, fhameed@jhu.edu

\footnotetext{
${ }^{1}$ The author is a Ph.D. candidate at Johns Hopkins University and is currently in the Fiscal Affairs Department at the IMF. I would like to thank Christopher Carroll, William Allan, Taryn Parry, and Gunther Taube for their encouragement and insightful comments.
} 


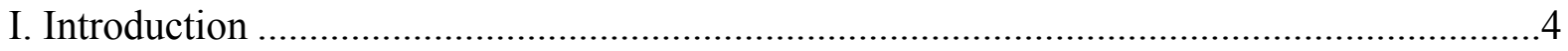

II. Why Fiscal Transparency? .....................................................................................

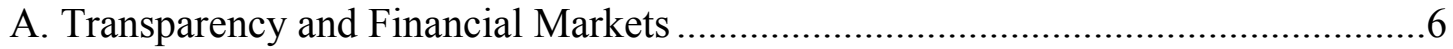

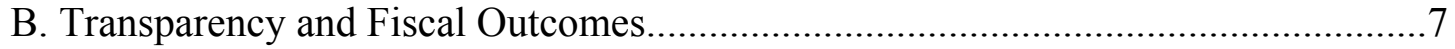

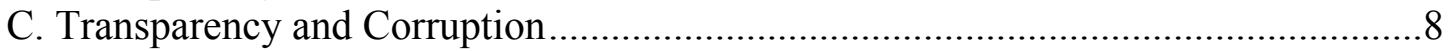

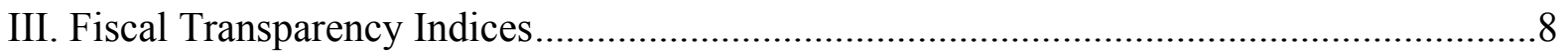

A. Fiscal Transparency ROSCs ....................................................................

B. Construction of Fiscal Transparency Indices ............................................. 10

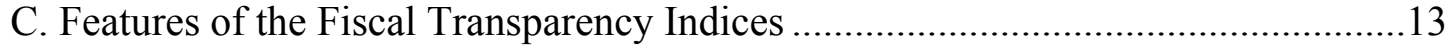

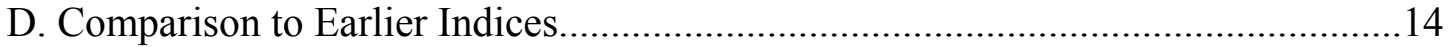

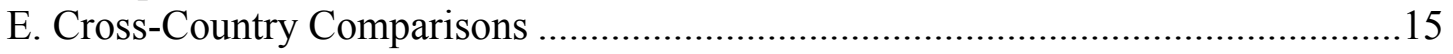

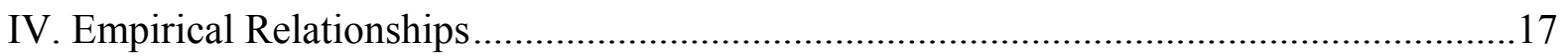

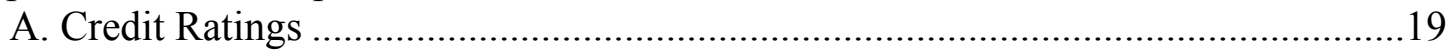

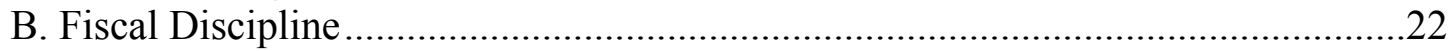

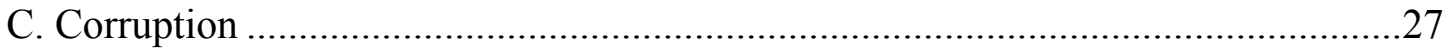

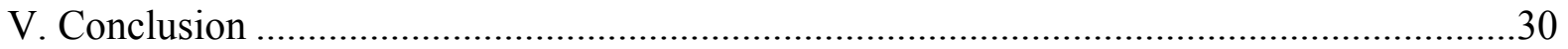

Tables

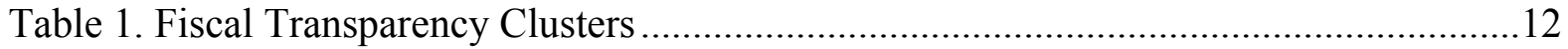

Table 2. Correlation among Fiscal Transparency Indices .............................................14

Table 3. Other Fiscal Transparency Indices ................................................................15

Table 4. Average Fiscal Transparency Indices ........................................................... 16

Table 5. Credit Ratings and Fiscal Transparency ........................................................ 21

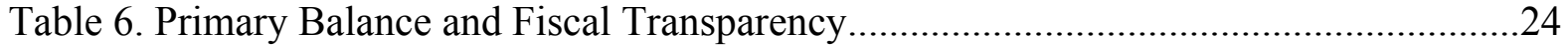

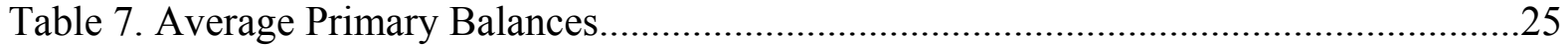

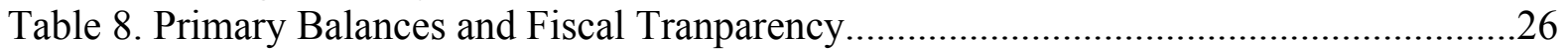

Table 9. Control of Corruption and Fiscal Transparency .................................................29

Figures

Figure 1. Income Rank and Fiscal Transparency..........................................................13

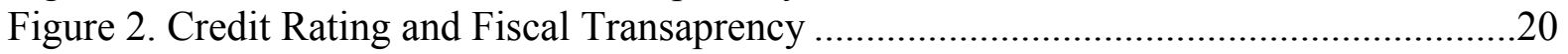

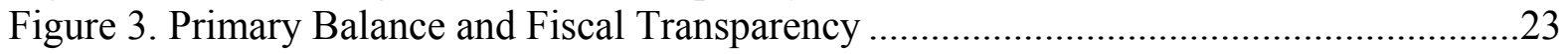

Figure 4. Control of Corruption and Fiscal Transparency ...............................................28

Appendices

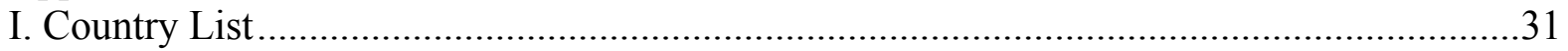

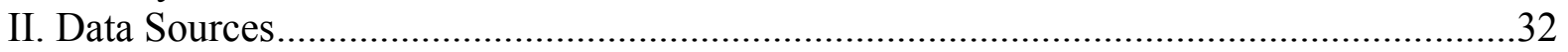




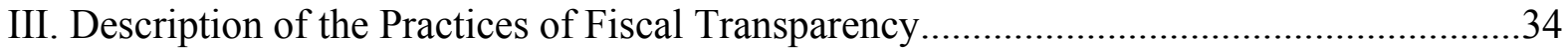

IV. Example: Classifying Practices on Contingent Liabilities ............................................37

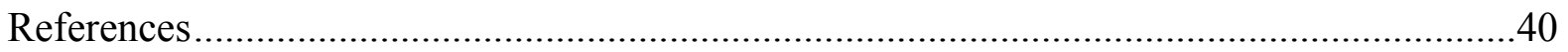




\section{INTRODUCTION}

In the past few years, transparency has received considerable attention from both policy makers and researchers. "Lack of transparency" was cited as a partial contributor to financial crises in Asia and Mexico. ${ }^{2}$ In a speech in 1999, the Managing Director of the IMF mentioned transparency as the "golden rule" for the new international financial architecture. ${ }^{3}$ There was renewed emphasis on acquiring information on country institutions and the transparency of these institutions. Such precepts helped lead to the development by the IMF and the World Bank of a range of standards of good practices covering various areas of the economy that are now internationally recognized and applied. ${ }^{4}$

This paper uses publicly available IMF staff assessments of the observance of the Code of Good Practices on Fiscal Transparency (the fiscal transparency code) to empirically examine several claims regarding the fiscal transparency code. It was argued that the adoption of these practices would, among other benefits, bring increased credibility resulting in a lower premium in the financial markets. Kopits and Craig (1998) recognizes that it is difficult to establish a causal link between fiscal transparency and fiscal discipline, but argues that "the better-performing countries ... generally follow more transparent fiscal practices." Further, Tanzi (1998) suggests that the Code of Good Practices on Fiscal Transparency, "if followed, would have the effect of reducing corruption." This paper will examine each of these issues in turn by considering whether countries with more transparent fiscal practices have more credibility in the market, better fiscal discipline, and less corruption.

A main contribution of this paper is development of a new fiscal transparency indices based on publicly available Reports on Observation of Standards and Codes (ROSCs) for the Code

\footnotetext{
${ }^{2}$ IMF (2001b) notes that a "lack of transparency was a feature of the buildup to the Mexican crisis of 1994-95 and of the emerging market crises of 1997-98" and that "inadequate economic data, hidden weaknesses in financial systems, and a lack of clarity about government policies and policy formulation contributed to a loss of confidence that ultimately threatened to undermine global stability."

${ }^{3}$ See IMF Survey, June 7, 1999.

${ }^{4}$ The Executive Boards of the IMF and World Bank have endorsed a list of 12 areas for standards assessments as follows: Data Transparency, Fiscal Transparency, Monetary and Financial Policy Transparency, Banking Supervision, Securities, Insurance, Payments Systems, Corporate Governance, Accounting, Auditing, Insolvency and Creditor Rights, and Anti-Money Laundering and Combating the Financing of Terrorism.
} 
of Good Practices on Fiscal Transparency. ${ }^{5}$ Although text-based, the ROSCs provide an important systematic database of information on transparency-related institutional features. ${ }^{6}$ The particular sub-indices of transparency considered include data assurance, medium-term budgeting, budget execution reporting, and fiscal risks disclosure. A major obstacle in empirical institutional work is that by their nature, institutions are difficult to quantify. Even when data are available, it is difficult to find consistent cross-sectional data for a large group of countries. Most of the previous research on transparency has focused on a small group of countries such as member countries of the European Union (EU) and the Organization for Economic Cooperation and Development (OECD), Latin American countries, and Central and Eastern European countries. ${ }^{7}$ This paper attempts to remedy this situation by constructing a broad indices for 57 countries $^{8}$ over a range of geographic locations, development stages, and institutions.

The paper will first present a definition of fiscal transparency, followed by a brief overview of earlier empirical literature on transparency and a discussion on why fiscal transparency matters. A description of the construction methodology and some properties of the indices will follow. The empirical relationships between transparency and market credibility, fiscal discipline, and corruption will be discussed in the third section. The paper will conclude with an agenda for future research.

\section{Why Fiscal Transparency?}

Before discussing the relevance of fiscal transparency, it is important to describe what it means. Kopits and Craig (1998) define fiscal transparency as:

"Openness toward the public at large about government structure and functions, fiscal policy intentions, public sector accounts, and projections. It involves ready access to reliable, comprehensive, timely, understandable, and internationally comparable information on government activities - whether undertaken inside or outside the government sector - so that the electorate and financial markets can accurately assess the government's financial position

\footnotetext{
${ }^{5}$ The two other existing indices which attempt to quantify fiscal transparency are by Oxford Analytica and International Budget Project (IBP), but these are available for a limited number of countries and constructed differently. These will be discussed later in the paper.

${ }^{6}$ Textual information is converted to numerical data by classifying the different levels of transparency practices over discrete categories between 0 and 1 .

${ }^{7}$ See Von Hagen (1992), Alt and Lassen (2003), Stein and others (1999), and Ylaoutinen (2004).
}

${ }^{8}$ More Fiscal Transparency ROSCs have been completed since the inception of this project and will be included in future revisions. 
and the true costs and benefits of government activities, including their present and future economic and social implication."

Focusing on non-transparent practices, Alesina and Perroti (1996) point out overly optimistic macroeconomic and fiscal assumptions; off-budget activities; and shifting of expenditures to future years in multi-year budgets as examples of practices which can reduce transparency. Other non-transparent activities may include not reporting government guarantees, ineffective audit, or delaying release of "bad" news. The Code of Good Practices on Fiscal Transparency builds directly on the Kopits and Craig (1998) definition of fiscal transparency (above). As discussed further below, the code describes thirty-seven practices under four general principles that represent different dimensions of transparency and accountability. The data derived from these observations thus allow a more detailed examination of different aspects of fiscal transparency than is available elsewhere.

The following sections will discuss why fiscal transparency matters for the particular variables of interest, namely credit ratings, fiscal discipline, and corruption. Although many papers have considered the impact of other economic and institutional explanations for these variables, very few have looked at fiscal transparency directly.

\section{A. Transparency and Financial Markets}

Kopits and Craig (1998) suggest that one of the main channels through which transparency may affect economic outcomes is through financial markets. Controlling for economic fundamentals, international financial markets are likely to demand lower premiums from governments that are forthcoming about their fiscal position and risks. The argument is that markets can be more certain about a fiscally transparent government's ability and willingness to service its obligations. Various transparency-related measures have been shown to affect credit ratings, sovereign spreads, foreign direct investment (FDI), and asset allocation.

Glennerster and Shin (2003) find that sovereign spreads decline following the adoption of transparency-related reforms such as publication of IMF country surveillance reports, release of different ROSCs, and compliance to SDDS. ${ }^{9}$ IIF (2002) and Christofides and others (2003) show that compliance with SDDS matters for sovereign ratings and spreads. They also consider other measures such as corporate transparency, accounting standards, and corruption, finding that they are important for sovereign ratings and spreads. Gelos and Wei (2002), using various indices of government and corporate transparency, show that emerging market equity funds hold fewer assets in less transparent countries, and herding among funds

\footnotetext{
${ }^{9}$ Special Data Dissemination Standard (SDDS) was established in 1996 to guide countries, that either have or might seek access to international capital markets, in the dissemination of economic and financial data to the public.
} 
is somewhat less prevalent in more transparent countries. ${ }^{10}$ Drabek and Payne (2001), using a composite government transparency measure, find that high levels of non-transparency can have a detrimental impact on FDI flow. ${ }^{11}$

Although these studies consider more general measures of transparency, they show that transparency matters to the markets. This paper argues that more fiscally transparent countries have higher credibility in the markets. Market reaction to fiscal transparency should be reflected in credit ratings, after controlling for certain economic fundamentals. In particular, greater disclosure of fiscal risks and a clearer medium-term strategy are likely to reduce uncertainty about the government's fiscal position and lead to improved ratings.

\section{B. Transparency and Fiscal Outcomes}

In the last decade, institutional explanations of fiscal outcomes have been an active area of research. Several papers have developed indices of "budget institutions" focusing on budget procedures such as: the power of the finance minister vs. other cabinet members; amendment rules; flexibility in budget execution; and budget negotiation among political parties. ${ }^{12}$ These studies generally find that "budget institutions" influence fiscal outcomes. Some of these papers, like Von Hagen (1992), consider fiscal transparency separately. But instead of deriving the information from observations of budget systems, the survey respondents were asked directly if the budget was transparent.

Lastly, Alt and Lassen (2003) undertook one of the few studies which focuses directly on fiscal transparency, but it is limited to OECD countries. A career-concern model with political parties is used to derive a testable hypothesis that higher transparency is associated with lower equilibrium debt. A measure of fiscal transparency is constructed based on a self-reported 1999 OECD Questionnaire, and the results show that debt is indeed negatively related to fiscal transparency in OECD countries. Some political drivers of fiscal transparency are also proposed including political competition, common law history, and presidential systems.

\footnotetext{
${ }^{10}$ Government transparency measure is a combination of the fiscal and monetary policy index produced by Oxford Analytica based mostly on IMF ROSCs for 27 market access countries.

${ }^{11}$ Government transparency measure is based on rankings in the International Risk Guide published by Political Risk Services for level of corruption, law and order, bureaucratic quality, contract viability, and risk of government appropriation of private assets.

12 See Von Hagen (1992), Alesina and others (1996), Stein and others (1999), Hallerberg and Von Hagen (1999), and Ylaoutinen (2004).
} 
This paper will argue that after controlling for certain institutional and economic differences, a more transparent government is likely to be more fiscally disciplined. If the government is forced to produce quality budget execution data and take stock of its fiscal risks, there is a lower probability of a large surprise deficit. The fiscal transparency manual, which elaborates on the code of best practices, suggests that governments move towards a medium-term budgeting framework. If the governments set their budgets in the medium-term and publish their plans in a way that can be monitored, a more disciplined fiscal policy is likely to result.

\section{Transparency and Corruption}

Are countries that are more fiscally transparent also less corrupt? Although much broader issues such as rule of law, effectiveness of the judiciary, and civil services reform are critical for reducing corruption, there are some obvious channels through which fiscal transparency can affect corruption. Increased accountability and more effective auditing is likely to reduce opportunities for some forms of corruption. If the government publishes planned budgets and budget execution reports for programs, those outside the government such as intended beneficiaries, civil society, and policy analysts can readily hold the executive accountable. ${ }^{13}$ Strengthening internal and external audit functions should reduce misuse/mismanagement of public funds.

\section{Fiscal TransParency INDICES}

This section will start with a brief discussion of the source data and the methodology used for the construction of the fiscal transparency indices. For purposes of analysis, the data are organized into four main clusters: data assurances, medium-term budgeting, budget execution reporting, and fiscal risk disclosure. This will be followed by some comments on the properties of the indices. The section will conclude with a discussion on correlations with earlier measures of fiscal transparency and cross-country comparisons. ${ }^{14}$

\footnotetext{
${ }^{13}$ Reinikka and Svensson (2004) cite an example in Uganda where an information campaign by the government, listing the amounts of grants at schools, led to a reduction in slippage after controlling for other demographic and school-specific data. The information provided to the schools and parents allowed them to hold the district officials accountable and to better understand and monitor the grants program.

${ }^{14}$ As noted earlier measures of fiscal transparency are available for a limited number of countries with few overlaps.
} 


\section{A. Fiscal Transparency ROSCs}

The Code of Good Practices on Fiscal Transparency was approved by the IMF Board in $1998 .{ }^{15}$ The code is divided into four sections with thirty-seven elements. The four main sections of the code are: clarity of roles and responsibility; public availability of information; open budget preparation, execution, and reporting; and assurances of integrity.

The IMF and World Bank publish assessment reports for each of the 12 standards and code modules called ROSCs. Participation in preparation of ROSCs is voluntary and the members retain the right to decide on publication. Since the inception of the Fiscal Transparency ROSC program, over 65 ROSCs have been completed with over 60 published. ${ }^{16}$ This study excludes the unpublished ROSCs and the initial ROSCs because they were experimental and, in some cases, self-assessments. Many of the earlier ROSCs have been updated several times and are published as separate documents. The information used to construct the indices includes all the updates and published ROSCs. ${ }^{17}$ The quality of ROSCs has generally improved over time with increased detail, comprehensiveness, and organization.

Most "good practice" elements of the transparency code have several components and cover a wide range of topics. ${ }^{18}$ The reports for each country note the extent of observation of practices in the fiscal transparency code. The ROSCs are textual in nature, and the organization of the report does not strictly follow the code. So, the first step was to divide the report according to elements of the code. ${ }^{19}$ Then, the textual information was used to assign numerical categories to selected practices.

${ }^{15}$ http://www.imf.org/external/np/fad/trans/code.htm\\#code

${ }^{16}$ All the published reports are available on the IMF ROSC website at http://www.imf.org/external/np/rosc/rosc.asp?sort=topic $\backslash \#$ FiscalTransparency. Since the inception of this paper, several additional ROSCs have been published which will be included in future analysis.

${ }^{17}$ Although this study does not have a time-series dimension to it, the future research agenda includes introducing a time series component considering the updates separately. Further, it is envisaged that on average the countries will be reassessed every 4 years, allowing a richer analysis of changes in practices of fiscal transparency.

${ }^{18}$ For example, element 2.1.3 states that "Statements describing the nature and fiscal significance of central government contingent liabilities and tax expenditures, and of quasifiscal activities (QFAs), should be part of the budget documentation." So this particular element covers a range of topics including contingent liabilities, tax expenditures, and QFAs.

${ }^{19}$ As a matter of routine, the Fiscal Transparency Unit of the IMF's Fiscal Affairs Department assigns all observations to each element of the code. The practice of including specific code elements is being incorporated in future publications of fiscal ROSCs. 


\section{B. Construction of Fiscal Transparency Indices}

This paper develops a summary index of fiscal transparency and four sub-indices including data assurances, medium-term budgeting, budget execution reporting, and fiscal risk disclosure. ${ }^{20}$ The selection of different aspects of transparency was driven by three main considerations: earlier literature on fiscal transparency, information content/classification, and tractability. ${ }^{21}$ The practices included in each cluster of fiscal transparency can be seen in Table $1 .{ }^{22}$

Even if a government publishes significant fiscal information, it is still possible for it to be considered non-transparent because of low quality data or unclear presentation. Therefore, the first sub-index looks at "data assurances" (DAS), i.e., practices which improve the reliability and credibility of fiscal data ${ }^{23}$ Good practices in this area would, for example, prevent presentation of an inaccurate picture of the budget through the use of overly optimistic macro-economic and fiscal forecasts. This problem is addressed in the Code of Good Practice on Fiscal Transparency by, for instance, suggesting that the governments invite independent experts to assess macroeconomic projections, fiscal projections, and the underlying assumptions. In other cases, using off-budget activity, varying the definition of government, and reclassifying revenue can hide the true extent of the deficit. So, transparency can be improved by adhering to a uniform classification of data (within government and across different levels of government) and using a widely accepted definition of government. These practices make it easier for those outside the government such as civil society, investors, and policy analysts to understand and analyze the budget.

The next cluster considered is the medium-term budgeting framework (MTBF). ${ }^{24}$ The particular practices included in this sub-index can be seen in Table 1. Government budgets are usually formulated on an annual cycle. But to be meaningful and effective, the budgets

\footnotetext{
${ }^{20}$ The descriptions of the 20 different practices included in the analysis can be found in Appendix III.

${ }^{21}$ For earlier literature on fiscal transparency see Allan and Parry (2003), Alt and Lassen (2003), and IMF (2003a). For more details on selection of aspects see Hameed \{2005).

${ }^{22}$ The second column in the table shows the correspondence between the practice considered and the relevant code from the Code of Good Practices on Fiscal Transparency.

${ }^{23}$ The accounting related reliability measures are discussed below under budget execution reporting.

${ }^{24}$ See Allan and Parry (2003) and the Manual on Fiscal Transparency for description of an MTBF.
} 
must take into account factors outside the budget cycle, such as long term investment plans, revenue trends, multi-year program costs, or macroeconomic realities. MTBF is a tool for better assessing, formulating, and implementing fiscal policy in the medium-term. Although an effective implementation of an MTBF requires a certain level of institutional sophistication, many governments with lower institutional capacity have adopted a phased approach to establishment of MTBFs by taking steps such as improving forecasting, formulating budget objectives, and costing new programs.

The proposed MTBF index attempts to capture the progress of this phased approach. A medium-term focus on the budget can enhance fiscal transparency through many channels. For example, the practice of distinguishing between the costs of continuing policies and new policies can improve transparency by making it easier to assess the factors contributing to deviations between planned and actual expenditures. It also becomes easier to establish a more direct link between the government's objectives and its budget proposal. Finally, considering the new policy costs separately may induce more disciplined medium-term budgets. A commitment to publishing forward estimates and explaining any drastic changes to projections is a major step toward policy accountability, and its adoption, is likely to lead to disciplined budgeting.

Disciplined budget execution is a crucial requirement for transparency and problems at the budget execution (BEX) stage can make any budget useless. An effective accounting system is a crucial part of budget execution. In addition, the index incorporates issues such as effectiveness of internal audits and external audits. In order to monitor the implementation stage, practices on mid-year reporting and publication of final accounts are also included.

Finally, a measure of disclosure of fiscal risk (FR) is also considered. There are several sources of fiscal risk that can affect a government's fiscal position either by increasing its obligations or reducing its resources. Requiring the government to publish information on possible sources of risk would present a more accurate picture of the fiscal position, improve credibility of the government by reducing uncertainty regarding its fiscal position, and may also prod the government to reduce sources of risk. The sources of fiscal risk considered include contingent liabilities, debt, and quasi-fiscal activity. ${ }^{25}$

Table 1 lays out the practices included in each of the sub-indices of transparency. Each practice was assigned a category $0,0.33,0.66$, or 1 , where 0 indicates weak practices, and a 1 indicates strong practices. ${ }^{26}$ In some cases, no information was reported for certain practices,

${ }^{25}$ Quasi-fiscal activities, such as directed lending or subsidized loans in the current period, may lead to losses/recapitalization in future.

${ }^{26}$ Appendix III defines each of the practices in more detail. For illustrative purposes, Appendix IV describes the classification methodology for contingent liabilities. The specific tables used to classify each practice can be found in Hameed (2005). Although the 
so these were noted as missing. For those practices that ask about publication of information, like contingent liabilities, the classification also takes into account the fact that some information may not be published because it is not relevant for the country. For example, a country that has limited contingent liabilities should not be classified lower even if it does not publish information on them. The summary index of fiscal transparency is calculated as a mean of all the practices listed in Table 1, and the sub-indices are calculated as means of their respective components. ${ }^{27}$

Table 1. Fiscal Transparency Clusters

\begin{tabular}{lll}
\hline \multicolumn{1}{c}{ Cluster } & \multicolumn{1}{c}{ Code 1/ } & \multicolumn{1}{c}{ Practices of Transparency 2/ } \\
\hline Data Assurance & 3.2 .1 & Budget Classification \\
& $2.2 .1,2.2 .2$ & Release of Data \\
& $2.1 .1,3.2 .1$ & Budget Coverage \\
& 4.2 .2 & Independent Assessment of Forecasts \\
& 4.1 .1 & Budget Realism \\
\hline Medium-term & 3.1 .1 & Policy Objectives \\
Budgeting & 2.1 .2 & Forward Estimates \\
& 3.1 .3 & Projections guided by Medium-term Quantitative Framework \\
& 3.1 .4 & New Policy Costs \\
& 3.1 .5 & Fiscal/Macro Risks \\
\hline Budget Execution & 3.3 .1 & Accounting System \\
& 4.2 .1 & External Audit \\
& 3.4 .2 & Final Accounts \\
& 3.3 .3 & Internal Audit \\
& 3.4 .1 & Mid Year Reporting \\
\hline Fiscal Risks & 2.1 .3 & Contingent Liabilities \\
& 2.1 .4 & Debt \\
& $2.1 .3,1.1 .4$ & Quasi-Fiscal Activity - Financial \\
& $2.1 .3,1.1 .4$ & Quasi-Fiscal Activity - NFPE 3/ \\
& 2.1 .3 & Tax Expenditures \\
\hline 1/ The elements of the Code of Good Practices on Fiscal Transparency are labeled 1.1.1 to 4.2.3. These & are the primary elements considered during classification, although in certain cases information from \\
other parts of the ROSC was also used. & \\
2/ See Appendix III for description of the different practices. \\
3/ NFPE - Non-financial Public Enterprises \\
\hline
\end{tabular}

classification involves judgment, the results should be close if others follow the same methodology.

${ }^{27}$ For robustness, the summary index was also calculated using random weights instead of equal weights. Although the analysis is not shown here, the index and ranking of countries are robust to these changes with slight variations. See a companion paper Hameed (2005). 


\section{Features of the Fiscal Transparency Indices}

The transparency of fiscal institutions varies considerably between countries with the actual index ranging from 0.95 to 0.18 . The most transparent countries are also the more advanced economies. This is not surprising since many of the practices in the Code of Good Practices on Fiscal Transparency were initially adopted in the more advanced economies. Several advanced economies have made conscious efforts to make transparency a corner stone of fiscal policy. On the other side of the spectrum are many developing countries, which have some of the least transparent practices in our sample. ${ }^{28}$

Figure 1. Income Rank and Fiscal Transparency

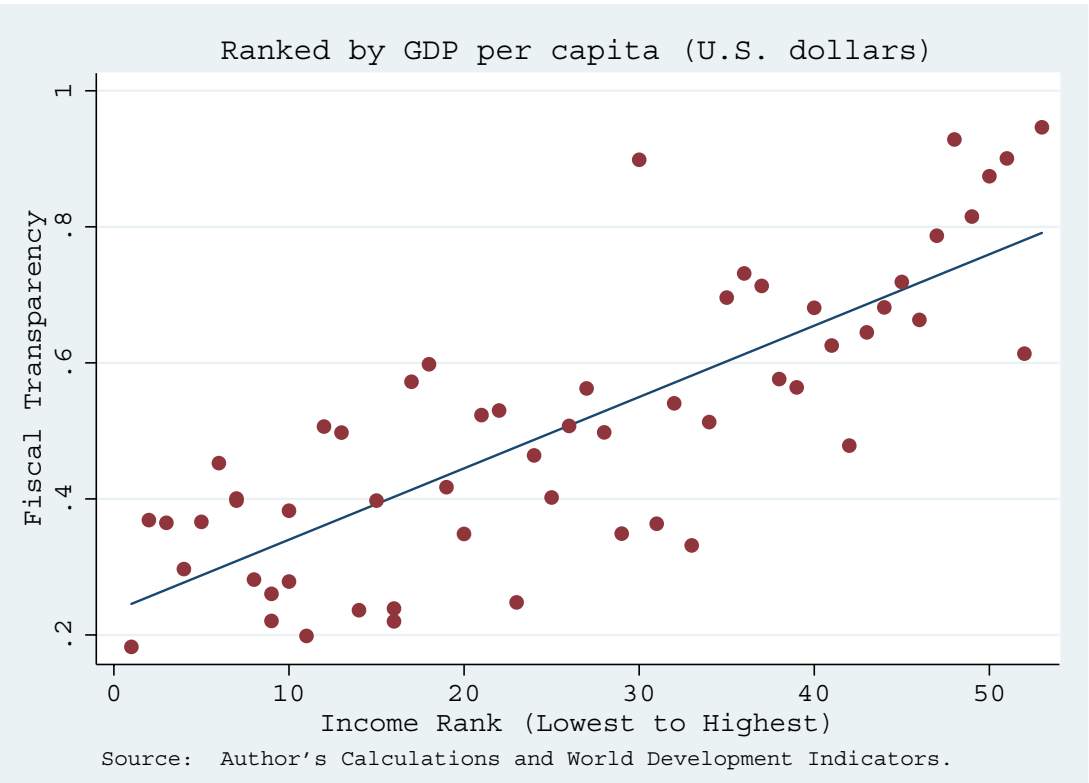

The sample of countries on the extremes suggests that transparency may vary systematically with income. Figure 1 plots the fiscal transparency against an index of countries sorted by current GDP per capita in U.S. dollars. It is clear that countries which rank higher in wealth

${ }^{28}$ It is important to note that this study only covers countries which have volunteered for a Fiscal Transparency ROSC. 
are also more transparent. ${ }^{29}$ A bivariate regression between fiscal transparency and income tells a similar story with a statistically significant positive coefficient. This finding is in accordance with earlier studies of institutions that invariably found a positive correlation between various measures of institutional quality and cross-country differences in GDP per capita. $^{30}$

Table 2. Correlation among Fiscal Transparency Indices

\begin{tabular}{lcccc}
\hline & FT & DAS & MTBF & BEX \\
\hline DAS & 0.87 & & & \\
MTBF & 0.84 & 0.66 & & \\
BEX & 0.82 & 0.66 & 0.51 & 0.66 \\
FR & 0.89 & 0.69 & 0.67 & \\
\hline
\end{tabular}

Source: Author's calculation.

FT - fiscal transparency

DAS - data assurances

MTBF - medium-term budgeting framework

$\mathrm{BEX}$ - budget execution reporting

FR - fiscal risks

The individual sub-indices are highly correlated, implying that better practices in one area of transparency are associated with better practices in other areas as well. This can be seen more clearly in the correlation matrix (Table 2) with all correlations greater than 0.50 .

\section{Comparison to Earlier Indices}

With the increased interest in fiscal transparency, some organizations such as the International Budget Project (IBP) and Oxford Analytica have started to develop fiscal transparency indices. Comparing the indices developed in this paper with earlier indices can provide a check for the methodology. Moreover, it can demonstrate the robustness of transparency results across different measures of fiscal transparency. Table 3 shows estimates for relationships between these indices and the FT indices based on fiscal ROSCs.

The IBP (2004), in a study of budget openness, developed different indices based on a detailed survey submitted to their affiliated organizations. These include an index on availability of executive budget documents (BUDDOC) and an index on availability of

${ }^{29}$ The paper takes no stance on causality between income and fiscal transparency since there are considerable endogeniety issues and also many common drivers for both of these variables.

${ }^{30}$ See IMF (2003b). 
monitoring and evaluation reports (MONEVL). There were 21 overlaps between the IBP sample and the ROSC sample. As can be seen in Table 3, each of the IBP measures is positively and significantly related to the summary fiscal transparency (FT) index. Since the BUDDOC variable poses a question similar to the data assurances (DAS) sub-index, the relationship between the two is also tested and found to be positive and significant.

Table 3. Other Fiscal Transparency Indices 1/

\begin{tabular}{lcccc}
\hline & $(1)$ & $(2)$ & $(3)$ & $(4)$ \\
& BUDDOC & $\begin{array}{c}\text { International Budget Project } \\
\text { MONEVL }\end{array}$ & BUDDOC & Oxford Analytica \\
& 0.60 & 1.02 & & 0.49 \\
\hline Fiscal Transparency & $(0.21)^{* *}$ & $(0.26)^{* * *}$ & & $(0.10)^{* * *}$ \\
Data Assurances & & & 0.45 & \\
& & & $(0.16)^{* *}$ & 13 \\
Obs. & 21 & 21 & 21 & 0.66 \\
$\mathrm{R}^{2}$ & 0.26 & 0.44 & 0.26 & \\
\hline
\end{tabular}

Source: Author's calculations.

Standard errors in parentheses

$*$ significant at $10 \%$; ** significant at $5 \%$; *** significant at $1 \%$

$1 /$ Other indices rescaled to 1 .

BUDDOC - availability of executive documents (IBP).

MONEVL - availability of monitoring and evaluation reports (IBP)

Oxford Analytica (2003) developed a fiscal policy transparency index as part of a report prepared for CalPERS(California Public Employees' Retirement System). Many of the Oxford Analytica observations are based on fiscal transparency ROSCs and other ROSCs, so one would expect a high correlation between the two indices. There were 13 overlaps between the two studies and a bivariate regression shows that the Oxford Analytica measure is indeed positively related to the summary fiscal transparency (FT) index developed here.

\section{E. Cross-Country Comparisons}

This section presents cross-county comparisons of the summary fiscal transparency index and the sub-indices. These comparisons can serve two purposes: first, to provide a further check on the index construction methodology by comparing earlier findings on fiscal transparency (based primarily on qualitative analysis) across groups of countries, and second, the comparison can suggest some new findings that can be explored further.

As can be seen in Table 4, the advanced economies as a group have higher fiscal transparency than the rest of the economies. Although there is variation within the groups, a $\mathrm{t}$-test for equality of means between groups assuming unequal variance rejects the null hypothesis of equal means. A one-sided test also confirms that the average transparency is greater in more advanced countries. A similar result arises when emerging market countries are compared to other non-advanced economies. 
The EU accession countries (many of them now new members of the EU) experienced significant institutional changes in order to meet the requirements for EU accession. ${ }^{31}$ These changes led to the adoption of many best practices in fiscal transparency, which placed the EU accession countries ahead of other non-advanced economies in terms of transparency. As Table 4 shows, EU accession countries indeed have higher average transparency index values when compared to the rest of the non-advanced economies and the difference is statistically significant. If the EU accession countries are compared only to other emerging markets, there is little difference between their mean transparency indices. ${ }^{32}$ However, a comparison with the advanced economies shows that the EU accession countries are still less transparent on average.

Table 4. Average Fiscal Transparency Indices

\begin{tabular}{lcccccc}
\hline & N & FT 1/ & DAS & MTBF & BEX & FR \\
\hline All & 57 & 0.51 & 0.55 & 0.51 & 0.54 & 0.43 \\
& & & & & & \\
Advanced Economies & 11 & 0.76 & 0.77 & 0.77 & 0.79 & 0.74 \\
Other & 46 & 0.44 & 0.49 & 0.45 & 0.48 & 0.36
\end{tabular}

(Excluding Advanced Economies)

\begin{tabular}{|c|c|c|c|c|c|c|}
\hline Emerging Market Countries & 12 & 0.57 & 0.63 & 0.58 & 0.63 & 0.45 \\
\hline Other & 34 & 0.40 & 0.44 & 0.40 & 0.43 & 0.32 \\
\hline EU Accession & 11 & 0.59 & 0.72 & 0.57 & 0.61 & 0.48 \\
\hline Other & 35 & 0.40 & 0.42 & 0.41 & 0.44 & 0.32 \\
\hline Latin America & 8 & 0.49 & 0.48 & 0.42 & 0.65 & 0.40 \\
\hline Other $2 /$ & 27 & 0.37 & 0.41 & 0.41 & 0.38 & 0.29 \\
\hline $\begin{array}{l}\text { Heavily Indebted Poor } \\
\text { Countries (HIPCs) } 3 /\end{array}$ & 13 & 0.33 & 0.29 & 0.45 & 0.31 & 0.26 \\
\hline Other 4/ & 15 & 0.37 & 0.46 & 0.32 & 0.45 & 0.28 \\
\hline
\end{tabular}

Source: Author's calculations.

$\mathrm{N}$ - number of countries in sample, FT - fiscal transparency, DAS - data assurances, MTBF - mediumterm budgeting framework, BEX - budget execution, FR - fiscal risks disclosure

$1 /$ A two-sample t-test for differences of means rejects the hypothesis that the means are equal at $10 \%$ confidence for each set of means.

2/ Excluding EU accession countries.

3/ Excluding advanced economies and emerging market countries.

4/ Excluding advanced economies, emerging market countries, and EU accession countries.

${ }^{31}$ See Allan and Parry (2003).

${ }^{32}$ Results are not shown in the Table 4. 
In Latin America, one of the institutional strengths has been the effective use of the financial management information system (FMIS). This has resulted in a higher quality of data on budget execution when compared to their counterparts elsewhere. ${ }^{33}$ The better practices are evidenced by a higher mean value for the Budget Execution (BEX) sub-index when compared to other countries, and the difference is statistically significant. At the same time, the difference of means is smaller for the other sub-indices of transparency.

Table 4 also compares the average transparency in Heavily Indebted Poor Countries (HIPCs) to other poor countries in the sample. ${ }^{34}$ The mean of the summary transparency index is not significantly different but the other poor countries perform better in terms of data assurances (DAS) and budget execution data reporting (BEX). One interesting feature is that the subindex on medium-term budgeting is statistically different and higher for HIPCs. The reason for this is likely that participation in the HIPC Initiative requires establishment of public expenditure tracking systems and detailed Poverty Reduction Strategy Papers. This has most likely led to improvements in practices such as statements of medium-term policies, establishment of medium-term economic frameworks, and forward estimates, practices that are captured in MTBF sub-index.

\section{EMPIRICAL RELATIONSHIPS}

The strategy in this section is to first identify a parsimonious model for each of the variables of interest (credit ratings, fiscal balance, and control of corruption) based on existing literature. Transparency indices are then added to the model to test if transparency is related to the variable of interest after accounting for the selected control variables.

The empirical section is limited to cross-section analysis because the fiscal transparency indices has no time variation. Many countries in the sample, such as EU accession countries, have gone through significant changes in the last decade. Therefore, any panel analysis would have to be limited to the last few years, thus precluding any meaningful analysis. As mentioned earlier, the future research agenda includes introducing a time series component considering the updates separately. If countries are reassessed every 4 years as planned, a much richer analysis of changes in practices of fiscal transparency would also become feasible.

\footnotetext{
${ }^{33}$ See IMF (2003a).

34 The HIPC Initiative is a program primarily carried out by the IMF and World Bank to provide multilateral debt relief to HIPCs which can demonstrate an established track record of macroeconomic performance.
} 
Another important theoretical consideration is the issue of endogeniety of fiscal transparency. Institutions drive economic conditions, but at the same time economic conditions can influence institutions. For example, a financial crisis may provide impetus for a country to implement significant institutional reform. In the existing institutional literature, the primary strategy for dealing with endogeniety is to use instrumental variables. But the theoretical and empirical work on fiscal transparency is still in its infancy, so a thorough discussion of instruments for transparency is proposed as a direction for future research. ${ }^{35}$ Endogeniety makes it difficult to claim causality between fiscal transparency and performance variables, but it is still useful to show correspondence between them.

Since the data are based on a cross-section of countries, all the regressions were tested for heterogeneity using the Breusch and Pagan test. In cases where there was evidence of heterogeneity, White standard errors are reported. ${ }^{36}$ Most of the models in this section, as in earlier studies, display multicollinearity, i.e., correlation between the control variables. So, for example, in the corruption model both income and education variables are included, and both are highly correlated. Theoretically, even with multicollinearity, OLS estimates are unbiased; but the variance of the estimated coefficients is higher. ${ }^{37}$ This means that it becomes more difficult to reject the null hypothesis that the coefficients are zero, but otherwise the problem of multicollinearity can be ignored.

Experience suggests that results in empirical institutional work maybe sensitive to country sample selection and choice of components included in the indices. To check for the robustness of results to sample selection, each model is re-estimated with a randomly selected 90 percent sub-sample. Each iteration notes if the coefficient on the transparency index is significant at 10 percent. The statistic of interest is the ratio of the number of times the coefficient is significant over all the iterations. A high (low) number indicates that the significance (or non-significance) is robust to sample selection. Although the results are not reported, the sign of the coefficient is robust to sample selection, and in most cases statistical significance is also robust to sample selection. Similarly, the results were found to be mostly robust to inclusion of different practices. Specifically, each model was re-estimated with a fiscal transparency index calculated excluding one or two randomly selected practices. In most cases, the coefficient on the fiscal transparency index remained positive and significant.

\footnotetext{
${ }^{35}$ Alt and Lassen (2003) suggest using political variables such as political competition, presidential system, and common law basis as instruments for transparency.

${ }^{36}$ These are heteroskedasticity-robust standard errors as described in Wooldridge (2001), pp. 55-58.

${ }^{37}$ See Wooldridge (2003), p. 97.
} 


\section{A. Credit Ratings}

The last decade has seen an unprecedented increase in international financial flows with a large number of countries accessing international credit markets. The number of countries with sovereign credit ratings has risen from 30 in 1980 to over a hundred in $2005 .^{38}$ Sovereign credit ratings assess a government's ability and willingness to honor its debt. ${ }^{39}$ Countries which are more transparent are more likely to convince the markets about their ability and willingness to honor their debt. This should be reflected in better credit rating, so a logical question to ask is whether more transparent countries have better ratings after controlling for other economic fundamentals.

Significant literature exists analyzing the determinants of risk proxied by credit ratings. Cantor and Packer (1996) find that rating assignments by Moody's and Standard and Poor's are related to a limited set of economic fundamentals including per capita income, growth, fiscal balance, external balance, external debt, economic development, and default history. Mulder and Perreli (2001) find that the ratio of debt to exports, rescheduling history, and ratio of investment to GDP have a significant impact on changes in ratings. Earlier papers on market effects of transparency have also considered sovereign spreads as a measure of risk. ${ }^{40}$ This section focuses on credit ratings because, first, composite sovereign spreads are available for a limited number of countries with fiscal transparency ROSCs, and second, previous literature has shown that credit ratings are strongly related to sovereign spread changes. $^{41}$

The credit ratings variable is an average of the Moody's, Standard and Poor's, and Fitch sovereign rating on foreign currency long-term debt for countries which have published fiscal ROSCs. Excluding the advanced economies, there are 31 countries which had published fiscal ROSCs and had sovereign credit ratings. The credit ratings observations were made mid-June of $2004{ }^{42}$ The alphabetical ratings were converted into numerical ratings using a simple alphabetical ranking with D (Default) $=1$ and AAA (Aaa for Moody's) $=22$. So a higher credit rating number indicates a better rating, i.e., lower risk of default.

${ }^{38}$ Primarily Moody's, Fitch, and Standard and Poor's.

${ }^{39}$ See Standard and Poor's (2002).

${ }^{40}$ See Christofides and others (2003) and Glennerster and Shin (2003).

${ }^{41}$ Ratings were shown to Granger cause changes in sovereign spreads by Reisen and Maltzan (1999). Kaminsky and Schmukler (1999) find that credit rating changes have a significant impact on sovereign spreads.

${ }^{42}$ The results were robust to observations at a different time and also averages over time. 
Figure 2. Credit Rating and Fiscal Transparency

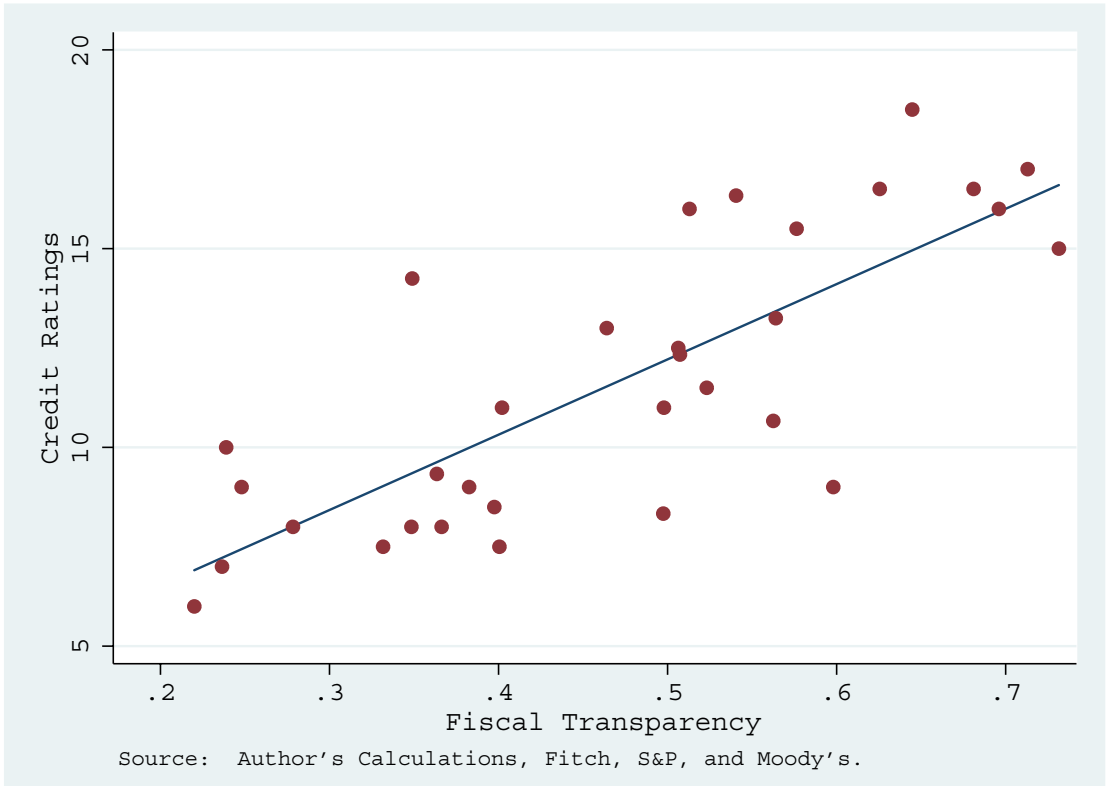

The advanced economies generally have high credit ratings, regardless of their transparency practices, mostly due to the market perception of their creditworthiness. This section focuses on emerging market countries and developing economies because they have a more realistic risk of sovereign default, and therefore are most likely to see an impact of more reliable information on current fiscal conditions and certainty about ability to pay. Figure 2 shows a positive relationship between credit ratings and fiscal transparency.

The core model for credit ratings includes current GDP per capita, growth, inflation, external debt, indicator for default history, external balance, and fiscal balance. ${ }^{43}$ Except for the default history indicator, a five-year average (1998-2002) of each variable is used. The income variable and growth variable are included to capture the potential tax base and the ability of the government to repay its debt. Problems with inflation can indicate structural problems in government finances, inflationary money supply, or general instability of the economy. The obvious reason for including external debt is that a greater debt burden increases the probability of default. The actual variable used is the external debt in percentage of exports. The default history variable indicates if a country has defaulted in the last 5 years. Primary fiscal balance and external balance (in percent of GDP) are included because they are important indicators of the government's available resources and financial sustainability.

${ }^{43}$ See Appendix II for data sources and description. 
Table 5. Credit Ratings and Fiscal Transparency

(Cross-section regressions, average 1998-2002)

\begin{tabular}{|c|c|c|c|c|c|c|}
\hline & (1) & (2) & (3) & (4) & (5) & (6) \\
\hline FT & $\begin{array}{c}18.94 \\
(2.74)^{* * *}\end{array}$ & $\begin{array}{c}8.19 \\
(2.56)^{* * *}\end{array}$ & & & & \\
\hline DAS & & & $\begin{array}{c}3.07 \\
(1.97)\end{array}$ & & & \\
\hline MTBF & & & & $\begin{array}{c}3.12 \\
(1.42)^{* *}\end{array}$ & & \\
\hline BEX & & & & & $\begin{array}{c}1.95 \\
(1.83)\end{array}$ & \\
\hline FR & & & & & & $\begin{array}{c}6.34 \\
(2.36)^{* *}\end{array}$ \\
\hline Obs. & 32 & 31 & 31 & 31 & 31 & 30 \\
\hline Adj. $R^{2}$ & 0.60 & 0.83 & 0.77 & 0.79 & 0.76 & 0.81 \\
\hline
\end{tabular}

Source: Author's calculations.

Standard errors in parentheses

* significant at $10 \%$; * significant at $5 \%$; ** significant at $1 \%$

FT - fiscal transparency, DAS - data assurances, MTBF - medium-term budgeting framework, BEX budget execution, FR - fiscal risks activity disclosure

The dependent variable in each column is sovereign rating.

Column (1) includes only the summary fiscal transparency index.

Column (2)-Column(6) include a core model in addition to the reported estimates where the core model includes GDP per capita in dollars, inflation, a default index, growth, external debt in percent of exports, fiscal balance and external balance in percent of GDP.

Table 5 shows the estimation results for various regressions of credit ratings over fiscal transparency. Column(1) includes only fiscal transparency and shows that there is a statistically significant and positive relationship between ratings and transparency with no controls. In order to reduce some omitted variable bias, a core model of credit rating is included in addition to the transparency variable. The core model alone explains about 76 percent of the variation in credit ratings. ${ }^{44}$ Most variables included in the model have the expected signs but many of them are not statistically significant. As mentioned earlier, this is most likely due to the presence of multicollinearity and limited degrees of freedom. This

${ }^{44}$ The estimated core model without any transparency index is shown below. The dependent variable is the average credit rating, and the second row shows the standard errors (See Appendix II for details of variables).

\begin{tabular}{cccccccc}
\hline CONS & GDPPC & INF & DEFIND & GR & XDEBT & CA & PB \\
10.0 & 1.00 & -4.93 & -1.86 & 27.89 & -0.63 & -2.70 & 10.45 \\
$(1.59)^{* * *}$ & $(0.25)^{* * *}$ & $(3.11)$ & $(0.93)^{*}$ & $(19.73)$ & $(0.34)^{*}$ & $(8.92)$ & $(12.59)$ \\
\hline
\end{tabular}


observation is similar to that of Cantor and Packer (1996), who find that although certain estimates had the right sign, they are not statistically significant. But the variables are still included in estimation, since there are appealing theoretical arguments for why they belong in the model.

The summary fiscal transparency index is added in column (2) of Table 5, which has a positive and highly significant coefficient. Adding fiscal transparency to the core model explains an additional 7 percent of the variation, with the adjusted $\mathrm{R}^{2}$ rising from 0.76 to 0.83 . Although the results of the core variables are suppressed in the interest of clearer presentation, the coefficients have the expected signs and are similar in size and significance to the estimates without any transparency indices (see footnote 44). It is difficult to give a quantitative interpretation to the value of the transparency coefficient but it is useful to consider the change in predicted rating with a change in transparency. For example, if countries in the lowest fifth quartile of transparency rise to the average transparency index for the highest fifth quartile in sample (0.68), the average rating changes from 7.9 to 11.7. This is an increase of 3.8 notches with a change in fiscal transparency from 0.27 to 0.68 . If they further improve transparency to 1 the predicted credit rating increases to 14.3 , which is investment grade. Each of the sub-indices are added individually in columns(3)-(7). ${ }^{45}$ The coefficients are positive in all the cases but are significant for only the medium-term budgeting frameworks (MTBF) and fiscal risks disclosure (FR) indices.

This section considered the relationship of market credibility, proxied by credit rating, and fiscal transparency. The results show that fiscal transparency matters for credit ratings. Specifically, after controlling for several economic fundamentals the results show that credit ratings are positively related to the summary transparency index (FT), medium-term budgeting frameworks index (MTBF), and fiscal risk disclosures index (FR).

\section{B. Fiscal Discipline}

In the last decade, many papers have appeared on relationships between political economy variables and fiscal policy outcomes, motivated by the observation that many outcomes could not be explained solely based on macroeconomic variables. ${ }^{46}$ The variables considered have included electoral rules, constitutions, finance minister turnover, and political stability. This section of the paper continues in a similar vein by asserting that fiscal policy outcomes are related to fiscal transparency. In particular, this section asks the question if more transparent countries display more fiscal discipline. A medium-term outlook of budget and careful stock

\footnotetext{
${ }^{45}$ A model including all the sub-indices and the core model was estimated but because of limited degrees of freedom and high correlation among the sub-indices, none of the coefficients on sub-indices were significant even though they were the right sign.

${ }^{46}$ See Persson and Tabellini (2001), Persson (2002), and Alesina and others (1996).
} 
taking of fiscal risks are likely to result in disciplined budgets. Moreover, strengthened budget execution reporting should also result in disciplined implementation of the budget.

Figure 3. Primary Balance and Fiscal Transparency

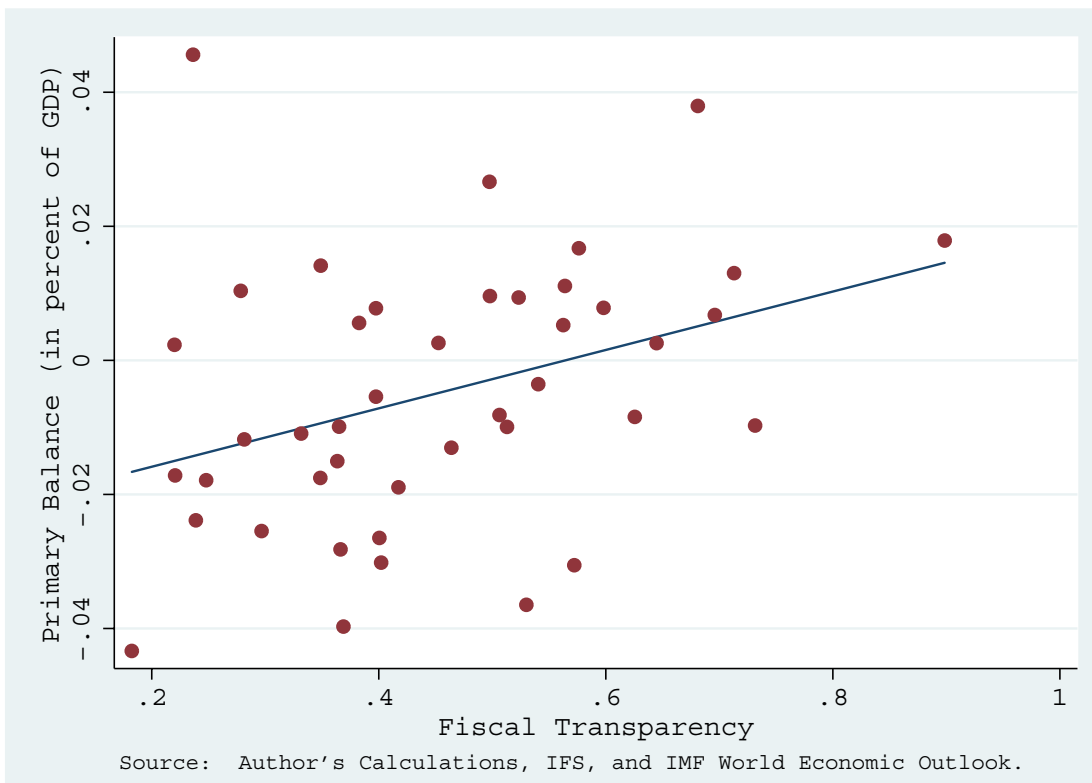

Fiscal discipline is proxied by the average primary balance over the last 5 years. Primary balance is a preferred measure of the government's fiscal stance because it abstracts from the effect of inflation on interest payments, and the fact that interest payments are a function of accumulated debt and not present fiscal stance. Again, the fiscal balances in more advanced economies are most likely driven by different dynamics than in non-industrial countries so the analysis here focuses on non-industrial countries. ${ }^{47,48}$ Figure 3 shows the average primary balances compared to fiscal transparency. Primary balances are higher for more transparent countries, though the data is highly dispersed suggesting the relationship may not be robust.

Simple bivariate regressions (shown in Table 6) tell a similar story. There is a positive and statistically significant relationship between primary balances and fiscal transparency (FT), DAS, MTBF, and FR. Contrary to expectations the coefficients on BEX, although positive, is not significant. The next section considers the relationships with some additional controls.

${ }^{47}$ See IMF (2003c) for the differences in fiscal policy reaction function.

${ }^{48}$ To reduce the impact of outliers, the analysis is limited to countries with primary balances within two standard deviations of the overall mean primary balance. As a result three countries were dropped from the analysis. 
Table 6. Primary Balance and Fiscal Transparency

(Bivariate Regression Results)

\begin{tabular}{|c|c|c|c|c|c|}
\hline & $(1)$ & (2) & (3) & (4) & (5) \\
\hline FT & $\begin{array}{c}0.04 \\
(0.02)^{* *}\end{array}$ & & & & \\
\hline DAS & & $\begin{array}{c}0.03 \\
(0.01)^{* *}\end{array}$ & & & \\
\hline MTBF & & & $\begin{array}{c}0.03 \\
(0.01)^{* *}\end{array}$ & & \\
\hline BEX & & & & $\begin{array}{c}0.01 \\
(0.01)\end{array}$ & \\
\hline FR & & & & & $\begin{array}{c}0.04 \\
(0.01)^{* * *}\end{array}$ \\
\hline Obs. & 43 & 43 & 43 & 43 & 42 \\
\hline Adj. $\mathrm{R}^{2}$ & 0.11 & 0.09 & 0.09 & -0.01 & 0.16 \\
\hline \multicolumn{6}{|c|}{$\begin{array}{l}\text { Source: Author's calculations. } \\
\text { Standard errors in parentheses } \\
* \text { significant at } 10 \% ; * \text { significant at } 5 \% ; * * \text { significant at } 1 \% \\
\text { Dependent variable is average primary balance in percent of GDP from } 1998-2002 \text {. } \\
\text { FT - fiscal transparency, DAS - data assurances, MTBF - medium-term budgeting framework, BEX - } \\
\text { budget execution, FR - fiscal risks disclosure }\end{array}$} \\
\hline
\end{tabular}

Another way of looking at the average data is by quartiles of fiscal transparency. If a positive relationship exists between fiscal transparency and fiscal discipline then countries in the higher quartile should have higher balances. Table 7 shows the average primary balance (Column (3)) over three quartiles of fiscal transparency. Although the average balances worsen for lower transparency quartiles, a t-test for the difference in means between the highest and lowest quartiles could not reject the null hypothesis that the means are equal. One possible reason for this may be the inclusion of HIPCs in the sample, which as discussed earlier have better MTBF indices than other poor countries, but at the same time their experience on fiscal balances has been varied. In order to control for difference due to being a HIPC, Table 7 considers fiscal transparency quartiles excluding HIPCs. In column (6), null hypothesis of differences between the top quartile and the lowest quartile can be rejected at 10 percent significance. Since the dynamics of primary balances and fiscal transparency are most likely affected by the HIPC process, the analysis with control variables excludes all HIPCs. 
Table 7. Average Primary Balances

(Fiscal Transparency Quartiles)

\begin{tabular}{lcccccc}
\hline & \multicolumn{2}{c}{ All } & & \multicolumn{3}{c}{ No HIPC } \\
Transparency & $\mathrm{N}$ & $\mathrm{FT}$ & $\mathrm{PB}$ & $\mathrm{N}$ & $\mathrm{FT}$ & PB \\
\hline High & 14 & 0.64 & 0.22 & 10 & 0.67 & 0.54 \\
Mid & 14 & 0.44 & -0.64 & 10 & 0.52 & -0.09 \\
Low & 15 & 0.29 & -0.99 & 11 & 0.32 & -1.03 \\
& 43 & & & 31 & & \\
\hline
\end{tabular}

Source: Author's calculations.

$\mathrm{N}$-number of countries in the relevant quartile.

FT-average fiscal transparency.

PB-average primary balance for the quartile group from 1998-2002 (In percent of GDP).

Certain economic/socio-economic variables are included in the analysis to control for variables which are likely to shape fiscal balances. The control variables, based on earlier literature, include a measure of development proxied by log of real GDP, openness measured as exports plus import over GDP, population size as log of population, percentage of population over 65 years old, and working age population measured as percentage of population between 15 and 65 years of age. ${ }^{49,50}$ The working age population ratio is included to capture the ratio of active tax paying population relative to dependents. Finally, initial debt, proxied by external debt in the year prior to beginning of the sample (1997), is also included since highly indebted countries need to run higher primary surpluses as a result of larger debt servicing obligations. ${ }^{51}$

Table 8 shows the estimates for the transparency indices including all the control variables. The core model without any transparency related variables has an adjusted $\mathrm{R}^{2}$ of 0.26 , once the transparency variables are added, the adjusted $\mathrm{R}^{2}$ increases up to 0.48 for MTBF. ${ }^{52}$

\footnotetext{
${ }^{49}$ See Alesina and others (1996), and Persson and Tabellini (2001) and (2004).

${ }^{50}$ The sources and description of data are given in Appendix II. Additional controls including geographic dummies and legal origin dummies are also used in the literature, but these would have severely reduced the degrees of freedom and thus were not included.

${ }^{51}$ The total public debt would be a more appropriate measure, but it is available for a limited number of countries. So, based on earlier studies, it is proxied by external debt.
} 
Table 8. Primary Balances and Fiscal Transparency

(Cross-section regressions with controls, average 1998-2002)

\begin{tabular}{|c|c|c|c|c|c|}
\hline & (1) & (2) & (3) & (4) & (5) \\
\hline FT & $\begin{array}{c}0.05 \\
(0.02)^{* *}\end{array}$ & & & & \\
\hline DAS & & $\begin{array}{c}0.03 \\
(0.02)\end{array}$ & & & \\
\hline MTBF & & & $\begin{array}{c}0.05 \\
(0.01)^{* * *}\end{array}$ & & \\
\hline BEX & & & & $\begin{array}{c}0.00 \\
(0.02)\end{array}$ & \\
\hline FR & & & & & $\begin{array}{c}0.03 \\
(0.02)^{*}\end{array}$ \\
\hline Obs. & 30 & 30 & 30 & 30 & 30 \\
\hline Adj. $R^{2}$ & 0.36 & 0.28 & 0.48 & 0.22 & 0.34 \\
\hline
\end{tabular}

Source: Author's calculations.

Standard errors in parentheses.

* significant at $10 \% ; * *$ significant at $5 \% ; * * *$ significant at $1 \%$

The dependent variable in each column is the five year average of fiscal balance in percent of GDP. The analysis excludes Advanced Economies and HIPC countries.

FT - fiscal transparency, DAS - data assurances, MTBF- medium-term budgeting framework, BEX budget execution, and FR - fiscal risks

Each column includes a core model in addition to the reported estimates. The core model includes log of real GDP per capita (PPP), trade openness, population size, percent of population over 65 and between 15 and 65 years of age, and external debt in percent of GDP in 1997.

The FT index in column(1) is positive and significant, implying that the more transparent countries are likely to have higher fiscal balances. If the lowest fifth quartile by transparency (0.28) improves transparency up to the highest fifth quartile (0.73), the average primary balance changes from -0.8 percent of GDP to 1.0 percent of GDP. Similarly, if the highest fifth quartile (0.73) is able to improve its transparency to 1 the predicted primary balance changes from 1.0 to 2.1 percent of GDP. Both MTBF and FR sub-indices appear to be

52 The estimated core model without any transparency index is shown below. The dependent variable is the primary fiscal balance and the second row shows the standard errors. Although the variables have the right signs, some are not significant.

\begin{tabular}{ccccccc}
\hline CONS & WORKPOP & OV65 & POP & OPEN & LPPP & XDEBT \\
-0.051 & -0.246 & 0.252 & 0.006 & 0.007 & 0.009 & 0.041 \\
0.089 & $(0.130)^{*}$ & $(0.127)^{*}$ & $(0.002)^{* *}$ & 0.012 & 0.006 & $(0.024)^{*}$ \\
\hline
\end{tabular}


driving the result with significant estimated coefficients. After including control variables, both DAS and BEX are no longer statistically significant though they still have the right sign.

It is important to point out that the relationship between transparency and fiscal discipline is likely to be stronger than suggested by these results. Countries which are less transparent are likely to be over-reporting their primary balances, which would negatively bias the relationship between primary balance and transparency. ${ }^{53}$ It is difficult to construct measures of the true deficits for less transparent countries because being less transparent means there is less information available.

This section considered the relationship between fiscal transparency indices and fiscal discipline. One clear result is that countries with higher MTBF indices, implying a more systematic medium-term outlook on budget, tend to have higher fiscal discipline after controlling for various economic/demographic variables. In addition, the summary transparency (FT) index and the fiscal risk (FR) measure are also significant. Surprisingly, the budget execution (BEX) measure shows no association with fiscal discipline.

\section{Corruption}

As noted in the introduction, several channels of corruption can be dampened by greater fiscal transparency, including increased accountability, less tax discretion, and more effective auditing. This section considers whether more transparent countries have lower corruption. Corruption is proxied by the "control of corruption" index by Kaufmann and Mastruzzi (2003), so a higher number implies less corruption. ${ }^{54}$ The index is based on a composite of several widely available sources on perception of corruption and attempts to measure the control over use of public power for private gain. Figure 4 below shows that transparency is positively correlated with control of corruption. The most transparent countries appear to have the greatest "control over corruption" but many of these countries are also the wealthier economies suggesting that some control variables need to be included in the estimation.

${ }^{53}$ They are also more likely to have higher off-budget activity.

${ }^{54}$ Although not shown, the results discussed below are robust to use of Transparency International (TI) (2004) corruption perception index (CPI) instead. Further, correlation between TI measure and "control of corruption" is 0.96 . The results for the "control of corruption" index are presented because it is available for a larger group of countries. The analysis uses the observation in 2002 , but the results are also robust to using an average over all available years. 
Figure 4. Corruption and Fiscal Transparency

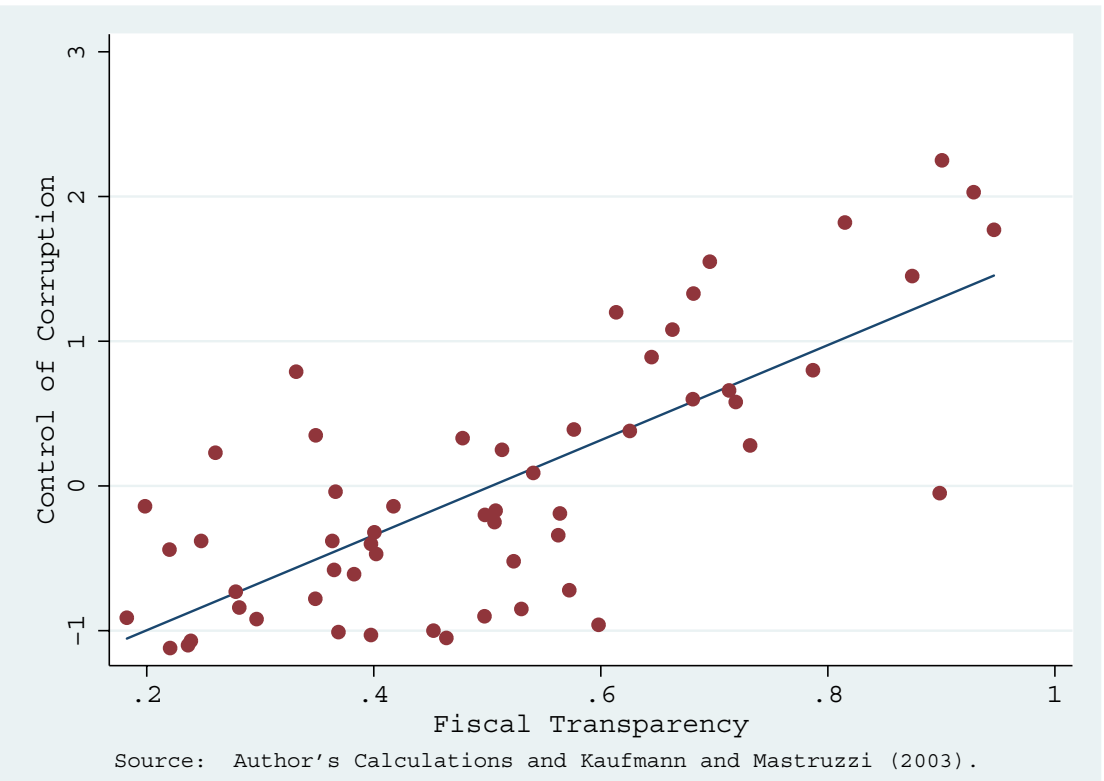

Several economic, social, historical, and geographical variables have been considered in earlier empirical studies of corruption. ${ }^{55}$ Measures of economic development, trade openness, fractionalization of the population, democracy, education, geographic location and legal origin were included as control variables. Economic development, proxied with log real GDP per capita and trade openness, defined as the sum of exports and imports as percentage of GDP, were included because earlier studies have shown that they are related to less corruption. Several studies have also found that fractionalization of the population is positively correlated with corruption. ${ }^{56}$ So an average of religious, ethnic, and linguistic fractionalization, calculated by Alesina and others (2003), is used as a measure of fractionalization. Level of democracy is proxied by the Polity IV democracy index. Education proxied by gross secondary school enrollment is used to control for the effect that a more educated population may be less likely to stand for government corruption.

Following earlier literature, dummy variables for continent location and legal origins are also included. $^{57}$

\footnotetext{
55 See Lambsdorff (1999) for a review. See Abed and Gupta (2002) and Persson and others (2000).
}

${ }^{56}$ See Mauro (1995) and La Porta and others (1999).

${ }^{57}$ See La Porta and others (1999). 
Table 9. Control of Corruption and Fiscal Transparency

(Dependent variable is control of corruption)

\begin{tabular}{|c|c|c|c|c|c|c|}
\hline & (1) & (2) & (3) & (4) & (5) & (6) \\
\hline FT & $\begin{array}{c}3.28 \\
(0.39)^{* * *}\end{array}$ & $\begin{array}{c}0.98 \\
(0.56)^{*}\end{array}$ & & & & \\
\hline DAS & & & $\begin{array}{c}0.23 \\
(0.42)\end{array}$ & & & \\
\hline MTBF & & & & $\begin{array}{c}0.68 \\
(0.35)^{* *}\end{array}$ & & \\
\hline BEX & & & & & $\begin{array}{c}0.37 \\
(0.43)\end{array}$ & \\
\hline FR & & & & & & $\begin{array}{c}0.57 \\
(0.40)\end{array}$ \\
\hline Obs. & 57 & 57 & 57 & 57 & 56 & 56 \\
\hline Adj. $R^{2}$ & 0.55 & 0.78 & 0.77 & 0.78 & 0.77 & 0.78 \\
\hline \multicolumn{7}{|c|}{$\begin{array}{l}\text { Source: Author's calculations. } \\
* \text { significant at } 10 \% ; * * \text { significant at } 5 \% ; * * \text { significant at } 1 \% \\
\text { Column (1) includes no controls } \\
\text { Column (2)-Column (6) include a core model with log real GDP, dummy for advanced economies, } \\
\text { dummies for geographical location, dummies for legal origin, trade openness, fractionalization, and } \\
\text { education. }\end{array}$} \\
\hline
\end{tabular}

Table 9 shows the coefficient estimates for the different transparency indices. Column(1) reemphasizes the conclusion from Figure 4, i.e., higher fiscal transparency is associated with greater "control of corruption" with a significant and positive coefficient. Once other control variables are added in columns (2)-column(6), the coefficients are smaller but still significant, with an adjusted $\mathrm{R}^{2}$ of $0.78 .^{58}$ The coefficient for the summary transparency index (FT) is positive and significant at 10 percent confidence level. If countries in the lowest 10th percentile of transparency (0.21) improve their transparency up to the highest 10 th percentile average $(0.91)$, they would see a change in control of corruption index from 0.8 to -0.04 . This is no where close to the control of corruption index value in the most transparent countries, which have an average index value of 1.49 . This indicates that

58 The coefficient estimates for the complete core model were suppressed in the interest of clarity of presentation. Most variables had the right sign but very few were significant, most likely because of collinearity. More "control of corruption" is associated with higher development, being an advanced economy, higher education, and more democratic regimes. Higher fractionalization, higher openness, and larger populations are associated with lower "control of corruption". Countries with legal origins in English or Scandinavian law seem to have relatively more control over corruption than others. These results are in-line with findings in earlier papers, except for openness which was earlier associated positively to "control of corruption." 
although transparency and corruption are related, much of the corruption is explained by other variables. All the coefficients for sub-indices of transparency are positive, but only the medium-term budgeting framework (MTBF) index is significant.

This section considered the incidence of corruption and fiscal transparency. After controlling certain geographical, economic, and demographic factors, the results show that countries that are more transparent also have better control over corruption. All the sub-indices were positively related to control of corruption but only the medium-term budget framework (MTBF) sub-index was statistically significant.

\section{Conclusion}

This paper describes a new indices of fiscal transparency based on reports of adherence to the Code of Good Practices on Fiscal Transparency. The indices are developed around four different clusters of practices: data assurance, medium-term budgeting, budget execution reporting, and fiscal risk disclosure. The analysis shows that the fiscal transparency indices are correlated with earlier related indices. A cross-country comparison of fiscal transparency indicates that advanced economies are more transparent, and the emerging market countries as a group are also more transparent than other economies. Transparency in EU accession countries, Latin America, and HIPC countries was also analyzed.

The paper examines the relationship of fiscal transparency to market credibility, fiscal discipline, and corruption. Fiscal transparency is associated with higher credit ratings even after controlling for various economic fundamentals. Although all the sub-indices considered had positive coefficients, they were only significant for fiscal risk disclosure (FR) and medium-term budgeting frameworks (MTBF). Countries with better practices in fiscal transparency also display more fiscal discipline even after controlling for certain socioeconomic variables. The significant sub-indices were medium-term budget frameworks (MTBF) and fiscal risk disclosure (FR). Similarly, control of corruption was also shown to be coincidental to fiscal transparency, and this result is robust to inclusion of several control variables. Only the medium-term budgeting frameworks (MTBF) index was significant when the sub-indices were considered individually.

A fruitful direction for future research would be to consider the determinants of fiscal transparency. One of the limitations of this study was the difficulty in establishing causality due to lack of appropriate instrumental variables. Alt and Lassen (2003) suggest political competition as an instrument for fiscal transparency, based on the observation that political parties prefer more transparency if there is a high probability that they might lose office in the next term. Other factors that may affect fiscal transparency could include level of democracy, existence of coalition governments, colonial history, and legal origins. Another proposed direction of future research is to consider the updates to ROSCs and second-round ROSCs separately to give a time-series dimension to the fiscal transparency index. This could provide some evidence on effects of changes in transparency and help pin down the direction of causality. 


\section{Country List}

\section{List of Fiscal ROSCs Included}

\begin{tabular}{lll}
\hline Advanced Economies 1/ & & Others \\
\hline Canada & Albania & Malawi \\
France & Armenia, Republic of & Mali \\
Germany & Azerbaijan Republic & Mauritania \\
Greece & Bangladesh & Mexico \\
Israel & Benin & Mongolia \\
Italy & Brazil & Mozambique, Republic of \\
Japan & Bulgaria & Nicaragua \\
Korea, Republic of & Burkina Faso & Pakistan \\
Portugal & Cameroon & Papua New Guinea \\
Sweden & Chile & Peru \\
United States & Colombia & Philippines \\
& Czech Republic & Poland, Republic of \\
& Estonia, Republic of & Romania \\
& Georgia & Rwanda \\
& Ghana & Slovak Republic \\
& Honduras & Slovenia, Republic of \\
& Hungary & Sri Lanka \\
& India & Tanzania \\
& Iran, Islamic Republic of & Tunisia \\
& Kazakhstan, Republic of & Turkey \\
& Kyrgyz Republic & Uganda \\
& Latvia, Republic of & Ukraine \\
& Lithuania, Republic of & Uruguay \\
\hline
\end{tabular}

1/ Based on IMF WEO country classification. 


\section{Data Sources}

- Advanced Economies - dummy variable which equals 1 if the IMF classifies the country as an advanced economy in its World Economic Outlook.

- BUDDOC - Index on availability of executive budget documents from International Budget Project, IBP (2004).

- External Balance (CA)- current account balance in percent of GDP from the International Financial Statistics (IFS) published by the IMF. In some cases the data was supplemented with World Economic Outlook database from the IMF.

- Control of Corruption - the control of corruption index from Kaufmann and Mastruzzi (2003) at the World Bank. Regularly updated and available online. See Kaufmann and others (1999) for development of the index.

- Credit Ratings (CR) - the alphabetical ratings from Fitch, Moody's and Standard and Poor's were converted to numeric ratings using a simple alphabetical ordering of the actual ratings. D (Default) $=1$ and AAA (Aaa for Moody's) $=22$. For countries which were rated by more than one agency, the average rating was used.

- Default History Indicator (DEFIND)- Equals 1 if country is reported to be in default for any one year during the sample period by Standard and Poor's; otherwise zero. See Standard and Poor's (2004).

- Democracy (DEMOC) - based on the democracy measure in the Polity IV dataset.

- Fractionalization (ELRF) - measured by an average of ethnic, linguistic, and religious fractionalization as presented in Alesina and others (2003).

- GDP per capita (GDPPC) - from the World Development Indicators database published by the World Bank.

- Geographic Location - dummy variables for the different continents based on location.

- Growth (GR)- annual change in real GDP per capita from the International Financial Statistics database published by the IMF.

- Inflation (INF) - annual change in CPI from the International Financial Statistics (IFS) database published by the IMF.

- Legal Origin - dummy variables for four main sources of legal origin: English, French, Scandinavian/German, and Socialist. Based on La Porta and others (1999). Supplemented with information from www.nationalmaster.com 
- Log of real GDP per capita (LPPP) - Log of real GDP adjusted for purchasing price parity as reported in the World Development Indicators, published by the World Bank.

- MONEVL - Index on availability of monitoring and evaluation reports from International Budget Project, IBP (2004).

- Trade Openness (OPEN) - calculated as the sum of exports and imports in percent of GDP. From the International Financial Statistics published by the IMF.

- Percentage of Population over 65 (OV65) - from the World Development Indicators published by the World Bank.

- Oxford Analytica Fiscal Transparency - Fiscal policy transparency index reported by Oxford Analytica (2004).

- Primary Fiscal Balance (PB) - fiscal balance minus interest payments in percent of GDP; from the World Development Indicators database published by the World Bank. In some cases the data were supplemented with World Economic Outlook database from the IMF.

- Population Size (POP) - from World Development Indicators published by the World Bank.

- Education (SSEN) - secondary school enrollment as reported in the World Development Indicators from the World Bank.

- Working age population (WORKPOP) - calculated as 1 minus the percentage of population below 15 years of age and over 65. From World Development Indicators published by the World Bank.

- External Debt (XDEBT) - from the World Development Indicators database published by the World Bank. Used both as percentage of exports (for Credit Rating Model) and as percentage of GDP (for Fiscal Balance Model). 


\section{Description of the Practices of Fiscal Transparency}

- Accounting System (BEX)- There should be a comprehensive, integrated accounting system which provides a reliable basis for assessing payment arrears. An effective accounting system is a fundamental requirement for transparency because it allows the recording of all government activity and establishes internal control to generate reliable budget execution data.

- Budget Classification (DAS) - Budget classification should be uniform and consistent with Government Finance Statistics (GFS) Manual 2001 (IMF (2001a)). This refers to the classification of budgets according to functional, economic, and administrative categories. Uniform classification of the budget along with use of a standard classification, such as GFS or European Statistical Agency (ESA) classification, makes it easier to get a clearer picture of the budget, government priorities, and magnitude/effectiveness of government programs.

- Budget Coverage (DAS) - Budget documents should cover all fiscal activity including all extra-budgetary transactions and activities of government autonomous agencies in order to provide a comprehensive picture of government finances.

- Budget Realism (DAS) - Budget projections should reflect the recent revenue and expenditure trends, underlying macroeconomic developments, and well-defined policy commitments.

- Contingent liabilities (FR)- Contingent liabilities should be published with budget documents. These are costs which the government will have to pay if particular event occurs; examples include loan guarantees, indemnities against certain risks, uncalled capital, or legal action. These can pose significant risk to future fiscal balances.

- Debt (FR) - Information on government debt should be regularly published. Most governments have better disclosure practices for external debt than local currency debt.

- External audit (BEX) - External audit should be independent, sound, and provided with sufficient resources. There should be effective follow-up of audit findings. A functioning external audit system is a basic requirement for transparency and an essential tool for assuring public accountability.

- Final Accounts (BEX)- Final accounts should be presented to the legislature and published within the following fiscal year. Final accounts should demonstrate compliance with budget, show major causes of deviations, and present an audited fiscal position of the government.

- Fiscal/Macro Risks (MTBF)- Major fiscal risk should be analyzed and reported where possible, including variations in economic assumptions and uncertain costs of specific programs. 
- Forward Estimates (MTBF) - Forward estimates at least two years ahead of the budget year should be included in the budget. This provides a medium-term outlook for budgeting and provides a benchmark for budgeting next year.

- Independent Assessment of Forecasts (DAS) - Macroeconomic and fiscal forecasts should be published and independent experts should be invited to assess these forecasts. This would improve the reliability of estimates and avoid surprises due to over optimistic projections.

- Internal Audit (BEX) - Budget execution should be internally audited and audit procedures should be open to review. Effective internal audit is an essential tool for preventing misuse and mismanagement of public funds.

- Medium-term Economic Framework (MTBF)- A medium-term quantitative macroeconomic framework should guide budget projections. This would ensure that fiscal policies are consistent with broader medium-term macroeconomic developments and other policies.

- Mid Year Reporting (BEX)- A mid-year report on budget developments should be published and presented to the legislature. This is an important tool for in-year monitoring of budget implementation and fiscal position.

- New Policy Costs (MTBF) - New policy costs should be clearly distinguished from the existing program costs in the budget documents.

- Policy Objectives (MTBF) - A statement of medium-term fiscal policy objectives (preferably with quantitative targets) should be included in the budget.

- Quasi-Fiscal Activity-Financial (FR)- The government should report any QFAs in the financial sector as part of the budget documentation. These include such practices as subsidized lending, loan guarantees, credit ceilings, and multiple exchange rates. QFAs in the financial sector pose fiscal risks because they weaken the financial institutions and may lead to higher future expenditure due to bail-outs and recapitalizations.

- Quasi-Fiscal Activity-NFPE (FR ${ }^{59}$ - The government should report any QFAs as part of the budget documentation. These include such practices as subsidized goods or services, cross-subsidization, and minimum prices for suppliers. QFAs distort the size of government expenditure, and pose fiscal risk because they may lead to losses at NFPE, requiring direct budgetary support in the future.

${ }^{59}$ NFPE - Non-financial public enterprises. 
- Release of Data (DAS) - Fiscal data should be released in a timely manner with sufficient detail and quality. The best practice is to publish advance release calendars for fiscal data. This improves transparency because discretion in fiscal data release can damage a government's credibility. Governments are likely to be more forthcoming with favorable rather than unfavorable information.

- Tax Expenditures (FR)- Any tax expenditure should be reported comprehensively in the budget documents. These include exemptions from the tax base, allowances, tax credits, tax rate reductions, and tax deferrals. Tax expenditures distort the size of government revenue and expenditure. 


\section{Example: Classifying Practices on Contingent Liabilities}

Contingent liabilities are a major source of fiscal risk in many emerging markets and developing countries. Contingent liabilities are not recognized in the balance sheet as such because they only become liabilities if certain events occur. Government guarantees to various financial and non-financial public enterprises are a common contingent liability, where in case of default the government is called upon to cover the loan amount. Contingent liabilities can also include indemnities, uncalled capital, and legal action against the government.

In order to identify the risks posed by contingent liabilities, element 2.1.3 of the Code of Good Practices on Fiscal Transparency suggests that "Statements describing the nature and fiscal significance of central government contingent liabilities... should be part of the budget document."

There are several ways to present a reasonable picture of the fiscal impact of contingent liabilities. Ideally, an actuarial estimate of fiscal risk posed by contingent liabilities should be included in the budget. This requires estimating the probability of contingent events (such as probability of a guarantee being called in) and the anticipated costs. This is not an easy task, since it is difficult to determine the a priori probability of a contingent event such as failure of a guaranteed enterprise. Further, liabilities such as indemnities and legal suits are difficult to quantify in advance. A more limited solution would be to present a statement on the value of all the quantifiable contingent liabilities such as guarantees and a statement of the amount of total guarantees that had been called in the previous fiscal year. Including this data in the budget document would give some idea of the risk posed by contingent liabilities and may lead to discussion about how best to deal with them.

The table below presents the array of possibilities for classifying practices on contingent liabilities. The rows classify the prevalence of contingent liabilities and the columns classify the reporting of contingent liabilities. Together, these two dimensions allow the classification of country practices into four levels $(0,0.33,0.66,1)$.

In order to apply this methodology, information is needed on both reporting of contingent liabilities and their extent. The practices on reporting in the budget can vary from "no reporting" to "comprehensive reporting." If countries do not report or collect information on contingent liabilities, they are assigned the category "Not reported/No quantitative information available." For those countries that do not report, there is a possibility that they may still record the information but have decided not to make that information public. The information may be available in the ministry of finance or elsewhere within the government. These cases are assigned "Not reported/Partial quantitative information available." Others may only publish partial information or may only list the liabilities without the quantities. These are assigned the category "Partially reported." If a country presents an actuarial estimate of contingent liabilities, or provides a list with the quantities of risk, then the country is classified as "Comprehensively reported." 


\section{Table 1. Contingent Liabilities}

2.1.3 Statements describing the nature and fiscal significance of central government contingent liabilities... should be part of the budget document.

\begin{tabular}{lccc}
\hline \multicolumn{1}{c}{ Extent } & Prevalent & $\begin{array}{l}\text { Somewhat } \\
\text { prevalent }\end{array}$ & Limited \\
\hline $\begin{array}{l}\text { Reporting in budget } \\
\begin{array}{l}\text { Not reported/No quantitative } \\
\text { information available }\end{array}\end{array}$ & 0 & 0 & 0.66 \\
$\begin{array}{l}\text { Not reported/Partial quantitative } \\
\text { information available }\end{array}$ & 0 & 0.33 & 0.66 \\
$\begin{array}{l}\text { Partially reported } \\
\text { Comprehensively reported }\end{array}$ & 0.33 & 0.66 & 1 \\
\hline
\end{tabular}

Similarly, the extent of contingent liabilities is difficult to assess, particularly if the authorities are not reporting them in the budget documents. FT ROSCs generally do not include any quantitative information such as total debt or total contingent liabilities. But many of the ROSCs have clear statement indicating whether the contingent liabilities are "limited" or "prevalent." In cases where it was not possible to determine the extent of liabilities, the countries were classified as "somewhat prevalent."

Countries where there is limited reporting and a high prevalence of contingent liabilities are assigned the category " 0 ." Countries where contingent liabilities are limited and practices on reporting are good are assigned category " 1 ." The numerical categories take into account the fact that some information may not be published because it is not relevant for the country. So countries where contingent liabilities are not reported but limited are assigned the same numerical category $(0.66)$ as countries where contingent liabilities are prevalent but comprehensively reported.

In order to see how the methodology works in practice, the next section discusses classification of practices on contingent liabilities for two countries A and B.

Country A was assigned the category " 1 " because it comprehensively reports its contingent liabilities which are limited. The "limited" assessment is based on the following statement in the FT ROSC:

"The Fiscal Risks Annex ... also discusses the contingent liabilities associated with public guarantees, and provides the value of outstanding guarantees, which traditionally have been small”' 
Similarly, on reporting, Country A is assigned the category of "Comprehensively reporting" in budget based on the following statement in fiscal ROSC:

"Information is provided on contingent liabilities.... As indicated above, ... includes detailed annexes on the securitization of unfunded liabilities incurred in the past, as well as a fairly detailed assessment of the contingent liabilities that may arise in the future (Fiscal Risks Annex)."

Based on its FT ROSC, Country B was assigned category " 0.66 " because contingent liabilities were deemed to be "prevalent" and there was "comprehensive reporting." The "prevalent" classification is based on the following statement in the FT ROSC:

"In 1998, the hidden liabilities were estimated to be around 13 percent of GDP, and the World Bank and the government estimate that they are expected to grow at a very fast rate."

On reporting, Country B is assigned category "comprehensively reported" based on the following statement in the FT ROSC:

"In 1998, the government began publishing information in the budget on the outstanding value of state guarantees granted by the MOF and other agencies....The government has taken steps to be transparent about the size of the problem by providing an inventory of its hidden debt, but it has not yet developed a clear policy initiative to deal with the problem." 


\section{References}

Abed, George T., and Sanjeev Gupta, eds., 2002, Governance, Corruption, and Economic Performance, (Washington D.C.: International Monetary Fund).

Alesina, Alberto, Ricardo Hausmann, Rudolf Hommes, and Ernesto Stein, 1996, "Budget Institutions and Fiscal Performance in Latin American," NBER Working Paper, No. 5586 (Cambridge, Massachusetts: National Bureau of Economic Research).

Alesina, Alberto, and Roberto Perotti, 1996, "Budget Deficits and Budget Institutions," IMF Working Paper 96/52 (Washington: International Monetary Fund).

Alesina, A., A. Devleeschauwer, W. Easterly and S. Kurlat, 2003, "Fractionalization," Journal of Economic Growth, Vol. 8 (June), pp. 155-194.

Allan, William, and Taryn Parry, 2003, "Fiscal Transparency in EU Accession Countries: Progress and Future Challenges," IMF Working Paper 03/163 (Washington: International Monetary Fund).

Alt, James E., and David D. Lassen, 2003, "Fiscal Transparency and Fiscal Policy Outcomes in OECD Countries," Economic Policy Research Unit Working Paper, No. 2003-2 (Paris: OECD).

Cantor, Richard, and Frank Packer, 1996, "Determinants and Impact of Sovereign Credit Ratings," FRBNY Economic Policy Review, Vol. 2 (October), pp. 37-53.

Center for International Development and Conflict Management (CIDCM), 2004, "Polity IV Dataset," University of Maryland, College Park. Available via Internet: www.cidcm.umd.edu/inscr/polity

Christofides, Charis, Christian Mulder, and Andrew Tiffin, 2003, "The Link Between Adherence to International Standards of Good Practices, Foreign Exchange Spreads, and Ratings," IMF Working Paper WP/03/74 (Washington: International Monetary Fund).

Drabek, Zdenek, and Warren Payne, 2001, "The Impact of Transparency on Foreign Direct Investment," Staff Working Paper ERAD-99-02, (Geneva: World Trade Organization).

Gelos, R. Gaston, and Shang-Jin Wei, 2002, “Transparency and International Investor Behavior,” IMF Working Paper 02/174 (Washington: International Monetary Fund).

Glennerster, Rachel and Yongseok Shin, 2003, "Is Transparency Good for You and Can the IMF Help?,” IMF Working Paper 03/132 (Washington: International Monetary Fund). 
Hallerberg, Mark, and Jurgen von Hagen, 1999, "Electoral Institutions, Cabinet Negotiations, and Budget Deficits in the European Union," In Fiscal Institutions and Fiscal Performance, ed. by James M. Porterba and Jurgen von Hagen (London: The University of Chicago Press, Ltd.).

Hameed, Farhan, 2005, “Indices of Fiscal Transparency” (unpublished; Washington: International Monetary Fund).

International Budget Project (IBP), 2004, “Opening Budgets to Public Understanding and Debate: Results from 36 Countries." Available via Internet: http://www.internationalbudget.org/openbudgets/index.htm

Institute of International Finance (IIF), 2002, "Appendix D: Does the Subscription to the IMF's Special Data Dissemination Standard Lower a Country Credit Spread," in Action Plan Proposals and Dialogue with the Private Sector (Washington: Institute of International Finance).

International Monetary Fund, 1999, Speech by the Managing Director at the 24th Annual Conference of the International Organization of Securities Commission in Lisbon, on May 25, 1999. Also reported in IMF Survey, June 7, 1999. ,2001a, Government Financial Statistics Manual (Washington: International Monetary Fund).

, 2001b, IMF Survey Supplement, Vol. 30, September, Washington, DC, p. 7-8

, 2003a, "Assessing and Promoting Fiscal Transparency: A Report on Progress," (Washington: International Monetary Fund). Available via Internet: http://www.imf.org/external/np/pdr/sac/2003/030503s2.htm.

, 2003b, World Economic Outlook April 2003: Growth and Institutions, World Economic and Financial Surveys (Washington: International Monetary Fund). , 2003c, World Economic Outlook September, 2003: Public Debt in Emerging Markets, World Economic and Financial Surveys (Washington: International Monetary Fund).

Kaminsky, Graciela L. and Sergio L. Schmukler, 1999, "What triggers market jitters: a chronicle of the Asian crisis?," International Finance Discussion Papers No. 634 (Washington: Board of Governors of the Federal Reserve System).

Kaufmann, Daniel, Aart Kraay, and Pablo Zoido-Lobaton, 1999, “Aggregating Governance Indicators," Policy Research Working Paper Series, No. 2195 (Washington: World Bank). 
Kaufmann, Daniel and Massimo Mastruzzi, 2003, "Governance Matters III: Governance Indicators 1996 - 2002," Policy Research Working Paper Series, No. 3106 (Washington: World Bank).

Kopits, George and Jon Craig, 1998, "Transparency in Government Operation," IMF Occasional Paper, No. 158 (Washington: International Monetary Fund).

La Porta, R. F. Lopez De Silanes, A. Shleifer, R. Vishny, 1999, “The Quality of Government," The Journal of Law , Economics, and Organization, Vol. 15 (March), pp. 222-279.

Lambsdorff, Johan G., 1999, "Corruption in Empirical Research-A Review," paper presented at the 9th International Anti-Corruption Conference, Durban, South Africa, December.

Mauro, P., 1995, “Corruption and Growth,” Quarterly Journal of Economics, Vol.106 (August), pp. 681-711.

Mulder, Chris and Roberto Perelli, 2001, "Foreign currency credit ratings for emerging market economies,” IMF Working Paper 01/191 (Washington: International Monetary Fund).

Oxford Analytica, 2003, "Permissible Markets Project, Fiscal Transparency Reports 2003." Available via Internet: http://www.calpers.ca.gov/eip-docs/about/press/news/investcorp/oa-fiscal-tran-03-ful-rpt.pdf.

Persson, Torsten, 2002, "Do Political Institutions Shape Economic Policy?," Econometrica, Vol. 70 (May), pp. 883-905.

, Guido Tabellini, and F. Trebbi, 2000, "Electoral Rules and Corruption," (unpublished; Stockholm: Institute for International Economic Studies).

, and Guido Tabellini, 2001, "Political Institutions and Policy Outcomes: What Are the Stylized Facts?," CEPR Discussion Paper No. 2872 (London: Center for Economic Policy Research).

, 2004, "Constitutional Rules and Fiscal Policy," American Economic Review, Vol. 94 (March), pp. 25-45.

Reinikka, Ritva and Jakob Svensson, 2004, "The Power of Information: Evidence from the Public Expenditure Tracking Survey," in Global Corruption Report 2004 (London: Pluto).

Reisen, Helmut and Julia von Maltzan, 1999. "Boom and Bust and Sovereign Ratings," International Finance, Vol. 2 (July), pp. 273-293. 
Standard and Poor's (2002), "Sovereign Credit Ratings: A Primer." Available via Internet: http://www.securitization.net/pdf/SovereignCreditRatings3402.pdf

Standard and Poor's (2004), "Sovereign Defaults: Set to Fall Again in 2005," CreditWeek, Vol. 24, No. 30, pp. 11-25.

Stein, Ernesto, Ernesto Talvi, and Alejandro Gristani, 1999, "Institutional Arrangements and Fiscal Performance: The Latin American Experience," in Fiscal Institutions and Fiscal Performance, ed. by James M. Porterba and Jurgen von Hagen (London: The University of Chicago Press, Ltd.).

Tanzi, Vito, 1998, "Corruption Around the World”, IMF Staff Papers, Vol. 45 (December), pp. 559-594.

Transparency International, 2004, Global Corruption Report (London: Pluto).

Von Hagen, Jurgen, 1992, "Budgeting Procedures and Fiscal Performance in the European Communities," Economic Paper, No. 96 (Hague: European Commission).

Wooldridge, Jeffery M., 2001, Econometric Analysis of Cross Section and Panel Data (Cambridge: The MIT Press). ,2003, Introductory Econometrics: A Modern Approach, 2e. (Cincinnati, Ohio : SouthWestern College Publishing).

Ylaoutinen, Sami, 2004, "Fiscal Frameworks in the Central and Eastern European Countries," Discussion Paper No. 72 (Finnish Ministry of Finance). 